\title{
The Effect of Industry-Level Aggregate Demand on Earnings: Evidence from the US
}

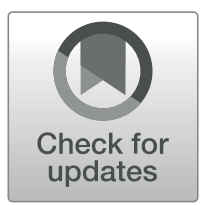

\author{
W. D. McCausland ${ }^{1} \cdot$ F. Summerfield ${ }^{2} \cdot$ I. Theodossiou $^{1}$
}

Published online: 18 April 2020

(C) The Author(s) 2020

\begin{abstract}
Economic theory suggests that workers' pay is mainly determined by their marginal product and that industry wage differentials may result either from the structure of the industry (demand type factors) or human capital characteristics of the employed labour force (supply type factors). This study uses a major data set from the US that allows the investigation of the effects of these demand and supply type factors on average earnings across industries. Importantly, this paper shows that aggregate demand relevant to the particular industry has a strong positive effect on the industry's average earnings in addition to the previously established results regarding the significance of the effects of worker and firm characteristics. Consequently, labour market policies crafted without due consideration of macroeconomic demand may be ineffective as a solution to the proliferation of low pay employment.
\end{abstract}

Keywords Macroeconomic demand · Industrial earnings

JEL Classification J31 · J63 · E24

\section{Introduction}

This paper assesses the impact of demand on average industrial earnings using measures of macroeconomic demand relevant to each particular industry. The analysis makes use of instrumental variable techniques and of the Annual Social and Economic Supplement (ASEC) of the US Current Population Survey (CPS) and the Job Openings and Labour Turnover Survey (JOLTS). The results suggest that macroeconomic labour demand has an important contribution over and above establishment-level demand

W. D. McCausland

d.mccausland@abdn.ac.uk

1 Department of Economics and Centre for European Labour Market Research, University of Aberdeen, Aberdeen, Scotland

2 Department of Economics, St. Francis Xavier University, Antigonish, Canada 
factors and labour supply type factors, such as personal and human capital characteristics. Isolating these effects provides a useful insight into the underlying mechanisms responsible for the considerable incidence of low paid employment in some industries. Although both demand and supply factors are responsible for the determination of earnings levels this study reveals that the level of aggregate demand within a specific industry has a significant positive effect on average earnings of that industry.

The context for this analysis is founded on a long-standing debate within the economic discipline. Classical and neo-classical labour market theory assumes that pay is largely determined by how productive the individual worker is and how effective market incentives are in mobilising his or her productive effort. Thus, the inference is that earnings differences mainly reflect individuals' relative productivity and hence low earnings are symptomatic of low levels of ability and skill. Consequently, the only important determinant of an individual's position on the earnings ladder should be expected to be the human capital they bring to the labour market and their inherent productivity. Mincer (1974) argued that "the model of worker self-investment as the basic determinant of earnings might be criticised as giving undue weight to the supply of human capital while ignoring the demand side of the market. Certainly, demand conditions in general, and employer investments in human capital of workers in particular, affect wage rates and time spent in employment, and thereby affect earnings. The present approach is initial and simple and greater methodological sophistication is clearly desirable" (page 137).

Yet, the theoretical and empirical investigations building upon the classical tradition have not yet included the effects of demand factors on the determination of earnings. Keynes (1936) contributed to understanding the marginal product of labour and the real wage, noting that both are uniquely determined when a particular state of organisation, industrial structure, equipment, and technique is assumed. His work advances the idea that, although the classical approach can explain real wages for a given volume of employment, it is macroeconomic demand that determines employment in the first place. In light of these insights, macroeconomic demand can be expected to have important policy implications for real wages in addition to those derived from a human capital framework.

Related theories that support an important role for demand include the job competition model (Thurow 1957). Following the Keynesian tradition, this model is based on the proposition that there is a queue of workers competing for jobs, with those at the head of the queue being hired first. Education determines the likelihood of getting a job, but only the particular level of education required for that job is directly rewarded in terms of pay. A more encompassing framework is captured by the assignment model (Tinbergen 1956; Sattinger 1993) which incorporates both supply and demand features of the labour market, by suggesting there is an allocation problem of assigning workers with various attributes to a range of jobs with differing levels of complexity. Precisely where workers are located determines the pay that they are likely to receive.

Furthermore, alternative approaches to labour market analysis (Bluestone 1970; Wachtel and Betsey 1972; Ryan 1990) suggest that relationships in the labour market are determined by industry structures, inequalities in bargaining power and deficient labour demand, and this can lead to the systematic underpayment of certain labour 
groups. The basic proposition is that the individual's position on the earnings ladder derives from the characteristics of the employing establishment rather than the worker. This approach focuses on the structure of the labour market and its impact on capabilities and the return to human capital of individuals.

Low paid workers are not spread evenly throughout all industries, even if they operate in similar product markets. They are usually concentrated in industries that have failed, for some reason or other, to provide a level of wage to their employees comparable to similar workers employed in similar industries. Isolating these reasons can provide some insight into the underlying mechanisms responsible for generating the increased incidence of low paid employment in some industries.

In view of the above, the focus of this study is the average earners in an industry and the forces affecting their earnings. It attempts to evaluate the effect of the average human capital characteristics on the average pay and, then, to evaluate the relative importance of those characteristics on the variation of industry average earnings compared to the industry's characteristics and the level of macroeconomic demand relevant to the particular industry.

There are several reasons why macroeconomic demand relevant to the industry can be expected to affect earnings, even conditional on other industry and worker characteristics. For instance, employers in particular industries or states where qualified labor is scarce may attempt to attract workers from other firms by offering a higher wage that also causes geographic and/or employer mobility among workers. Increased wages among new hires, ceteris paribus, may follow if firms find it optimal to compensate workers for relocation costs or for the loss of specific human capital. Using a search theory framework, Cahuc et al. (2006) shows that skilled workers can expect superior outside options and enjoy a higher bargaining power when high macroeconomic demand induces firms to post more vacancies.

In view of the above, this paper examines average earnings across 26 US industries over the period 1990-2012. The variable to be explained is always the average level of industry earnings by year and region or state. The explanatory variables include the average mix of human capital characteristics of employees in the industry, the characteristics of the industry (namely, average firm size and level of unionisation) and the level of macroeconomic demand relevant to the particular industry. The latter explanatory variable evaluates whether wages respond to excess demand.

The remainder of the paper henceforth is set out as follows. In the next section an overview of the pertinent literature on the industrial wage structure is presented. Section "Data" describes the data in the study, while "Estimation Methodology" discusses the methodologies employed. The results are discussed in "The Determination of Industry Earnings: OLS Estimates" through "The Causal Effect of Demand on Industry Earnings: IV Estimates" and conclusions and policy implications are offered in "Discussion and Conclusions".

\section{Overview of the Literature}

Human capital theory suggests that an individual's human capital endowment is the sole mechanism for someone getting and maintaining a well-paid job. Becker (1962), 
Becker (1964), and Mincer (1974) and Ben-Porath (1967) describe the contributions of experience and education to the earnings potential of individuals. A large literature estimating wage equations evaluates this theory (Heckman et al. 2003). Although noone could deny that skill supply through education, work experience and other human capital investments affect where workers fall in the earnings distribution, this study focuses on the contribution of industry characteristics and industry macroeconomic demand factors on the determination of earnings levels.

Classical economic theory suggests that competitive conditions in the labour market should ensure that labour is paid a wage which reflects its net productivity, where this has been adjusted for differences in working conditions. Earlier studies reveal that industry-specific variables play no part in competitive explanations of earnings differences (Pugel 1980). However, later studies reveal that industry effects account for between 7 to 30 per cent of the variation of non-union wage rates and 10 to 29 per cent of the variation of union wage rates in 1983 (Dickens and Katz 1987). There are several reasons offered in the literature as an explanation for some industries to pay more than others. Using Indonesian data, Amiti and Davis (2012) show that a fall in output tariffs lowers wages in import-competing firms but increases the wages paid by exporting firms. Tariffs have also been shown to cause wage premiums in certain industries in Columbia by creating rents (Goldberg and Pavcnik 2005b). Other industries may be characterised by employment contracts designed to circumvent regulation on pay and benefits. Brown and Sessions (2003) show that, in the UK, the increased use of fixed term contracts tends to reduce wages, and that this cannot be attributed to those on fixed term contracts having lower levels of education.

Krueger and Summers (1988) point to firm characteristics as an important source of wage differences across industries. Hence, average firm characteristics should be expected to affect industry average pay. The authors' conclusions are based on their findings that differences in earnings differentials persist, conditional on worker fixedeffects, and within occupations. Using matched employer-employee data, Abowd et al. (2012) confirm that high paying employers may exist if a desire for equity, within firms with many high-skill jobs, drives up the wages of other workers (Thaler 1989). Furthermore, in the UK, Metcalf (1999) points out that "the incidence of low pay is far higher among workers in the private than the public sector, among those in workplaces with no union recognition and in smaller rather than larger workplaces". It appears that eight sectors (mainly services) account for the bulk of the low paid workforce and no less than two-fifths of them are located in retailing and hospitality alone.

Other factors may be important in explaining why certain industries pay more. For example, the selection into jobs by workers facing wage discrimination may contribute to low pay. Using Canadian data, Baker and Fortin (2001) conclude that women are not low paid when they work in traditionally female jobs. The gender pay gap narrowed through the 1990s as women entered traditionally male occupations (Blau and Kahn 2000). However, recent studies suggest that non-cognitive skill differences may explain why a gap persists today (Grove et al. 2011). Other studies suggest that workers with higher infra-marginal tolerance for undesirable conditions are able to select into higher paying jobs (Gibbons and Katz 1992).

This paper offers an additional explanation, which has received little attention in the literature. The analysis is motivated in part by the findings of Du Caju et al. (2010) 
that show that employer, employee, and job characteristics together explain at most $40 \%$ of wage premium across industries. The focus in this paper is the evaluation of the possibility that an excess (or shortage) in the demand for labour in a particular industry could lead to higher (or lower) wages in that same industry, conditional on worker and firm characteristics. Research on how labour demand affects earnings is limited. Schumacher (2001) has found that as demand fell during health care restructuring in the US during the 1990s the fall in both the absolute and relative wages of nurses was unrelated to their personal characteristics. Furthermore, in investigating the effects of structural change within the US steel industry in the 1980s Beeson et al. (2001) has found that the decline in employment was accompanied by a fall in mean wages and a rise in the variance of wages, particularly for those on low wages and with poor education. The rise in wage inequality has been particularly evident for young males, and also has spilled over to firms in the supply chain.

The positive wage-effects of an increase in demand for labour documented in this study are related to studies which show that positive wage-effects follow increases in demand for college educated labour (Katz and Murphy 1992). Murphy and Welch (1993) and Juhn et al. (1993) link the increase in wages from 1940-1990 to increases in the demand for skilled (highly educated) workers. More recent changes in the wage structure are also linked to the demand for specific skill. Autor et al. (2003) and Autor et al. (2008) find that the polarisation of the US wage structure can be linked to a decrease in demand for middle-skill jobs which are increasingly off-shored. In Germany, there is evidence of polarisation which can be linked to change in the type of skill in demand by employers (Spitz-Oener 2006; Dustmann et al. 2009). Similar findings exist for the UK (Goos and Manning 2007) and other European Countries (Goos et al. 2009). Whereas these studies document nuanced changes in wage structure stemming from the demand for specific types of skill, this paper documents changes stemming from the macroeconomic demand relevant to the particular industry.

\section{Data}

This paper uses data from the Annual Social and Economic Supplement (ASEC, widely known as the March CPS) of the US Current Population Survey (CPS).

The data is drawn from a monthly US household survey conducted jointly by the US Census Bureau and the Bureau of Labour Statistics, comprising labour force and demographic questions, supplemented by the March CPS, which includes further questions on income, employment, poverty, health insurance and taxation (King et al. 2010). The data spans sixteen years $(t)$ from 1997-2013, twenty-six 1990 industry codes $(i)$ and 52 US states $(l)$. Personal characteristics used in the analysis include age, educational attainment, full-time/part-time employment status and gender. Characteristics of the firms employing respondents are also used. These characteristics include firm size and whether or not workers are unionised. To retain some homogeneity in the sample, self-employed workers and respondents younger than 15 are excluded.

The analysis is undertaken at the industry-region-level. Data for each variable are averaged within each unique cell of industry, US State and year (ilt) to obtain 
the appropriate level of aggregation in the data. This collapse of the data has the advantage of removing individual heterogeneity by averaging within each $i, l, t$ cell. Continuous variables such as age or years of education are first grouped into discrete categories that are more informative when collapsed. Education is represented by the share of employees holding a university degree or higher for each industry-regionyear group, firm size is captured by the shares of firms which have less than 10, 10-99 and more than 100 employees, and age is captured by groupings that represent the shares of workers less than age 25, age 25-45 and aged above 45. Summary statistics are presented in Table 1.

\section{Estimation Methodology}

The objective of the paper is to investigate the determinants of the position of the earnings of workers in particular regional industries within the earnings distribution. The basic hypothesis to be tested views the average wage in the industry as a function of both average personal characteristics of the employees in the industry (loosely supply-type variables) and the average establishment variables and other industry determined variables (demand-type variables). The important innovation of the paper is that, in addition to assessing the effects of the employees' average human capital and the effects of the structure of the industry on the position in the industry's average earnings, it also aims to assess the effects of the macroeconomic demand on the industry average pay.

Table 1 Variable description and summary statistics for cell-level data

US Current Population Survey (CPS), 1997-2013

\begin{tabular}{lllll} 
Variable & Description & Mean & SD & N \\
\hline Income $(w)$ & Wage income (1000s \$US per year) & 33.243 & 17.718 & 14183 \\
Vacancy Rate & Industry-level job vacancy rate & 2.507 & 1.006 & 10447 \\
Net Hiring Flow & Number of: (hires-fires)/employed & 0.973 & 0.105 & 13238 \\
New Hires & Number of new hires & 32.733 & 47.852 & 14309 \\
Redundancies & Number of fires/redundancies & 1.886 & 7.123 & 14309 \\
Male & Share of workers that are male & 0.540 & 0.248 & 14204 \\
Education & Share of workers with at least a Bachelor's degree & 0.250 & 0.211 & 14203 \\
Age $<25$ & Share of workers age <25 & 0.241 & 0.196 & 14204 \\
Age 25-45 & Share of workers age 25-45 & 0.489 & 0.200 & 14204 \\
Full Time & Share of workers with full-time permanent contracts & 0.812 & 0.187 & 14091 \\
Unionised & Share of workers covered by a union & 0.126 & 0.229 & 11479 \\
Firm Size $<10$ & Share of workers in firms with <10 employees & 0.152 & 0.160 & 14183 \\
Firm Size 10-99 & Share of workers in firms with 10-99 employees & 0.238 & 0.178 & 14183 \\
Employment & Number of employed persons (thousands) & 27.847 & 15.336 & 14309 \\
\hline
\end{tabular}

Cell-level data are original CPS data collapsed to mean values by industry-state-year combinations 
The literature supports an empirical connection between the industry wage level and the level of macroeconomic demand relevant to the specific industry that is related to worker hiring and firing patterns. A useful starting point in this regard is the wage curve (Blanchflower and Oswald 1995). The wage curve suggests a negative relationship between levels of unemployment and wage rates, when these variables are expressed in regional terms. In effect, unemployment acts as an approximation of the level of macroeconomic regional demand in this framework. Blanchflower and Oswald (1995) argue that the wage curve reflects the observation that a worker who is employed in a region of high unemployment (low regional demand) earns less than an identical individual who works in a region with low unemployment (high regional demand). Blanchflower and Oswald (1995) show that there is a stable relationship linking regional unemployment and the level of pay which is a downward-sloping convex curve.

The wage curve should also be relevant at the regional industry and occupation level. Thus, the wage curve for industry $i$ in region $l$ at time $t$ can be represented by Eq. 1.

$$
W_{i l t}=f_{1}\left(U_{i l t}\right)
$$

However, the unemployment rate, $U$, is in turn determined by labour market flows, namely the difference between the number of hired workers, $H$, and the number of worker redundancies (or fires), $R$, in relation to the total number of workers in the labour force, $N$. Equation 2 details this relationship at the regional industry level.

$$
U_{i l t}=f_{2}\left(\frac{\left(H_{i l t}-R_{i l t}\right)}{N_{i l t}}\right)
$$

Hence, taking together Eqs. 1 and 2 yields Eq. 3

$$
W_{i l t}=f_{3}\left(\frac{\left(H_{i l t}-R_{i l t}\right)}{N_{i l t}}\right)
$$

This formulation can then be used to provide an augmented form of the usual human capital earnings function where regional industry earnings differences at time $t$, $W_{i l t}$ are explained not only by human capital (person-level) characteristics, $\mathbf{P}_{i l t}$, and industry or firm characteristics, $\mathbf{F}_{i l t}$, but also by demand effects, $D_{i l t}$. In the earnings function shown in Eq. 4, the variable to be explained is the average earnings in the industry $i$ in region $l$ at time $t$. The explanatory variables include a number of human capital characteristics (age, gender, educational qualifications) defined as the average of the human capital characteristic in industry $i$ in region $l$ at time $t$, and respectively defined demand types variables, namely "industry structure" variables (level of unionisation and firm size) and a level of macroeconomic demand relevant to the industry.

$$
W_{i l t}=f\left(\mathbf{P}_{i l t}^{\prime}, \mathbf{F}_{i l t}^{\prime}, D_{i l t}\right)
$$

Following from Eq. 4, our main empirical model is outlined in Eq. 5 below.

$$
\begin{aligned}
\ln \left(w_{i l t}\right)= & \beta_{0}+\beta_{1} d_{i l t}+\beta_{2} m_{i l t}+\beta_{3} e_{i l t}+\beta_{4} p_{i l t}+\beta_{5} u_{i l t}+\beta_{6} c_{i l t}+\beta_{7} n_{i l t} \\
& +\mathbf{a}_{i l t}^{\prime} \theta+\mathbf{s}_{i l t}^{\prime} \lambda+\tau_{t}+\mathbf{I}_{i}+\mathbf{L}_{l}+\epsilon_{i l t}
\end{aligned}
$$


All variables in the model are expressed in terms of the industry-region level annual average. For a given characteristic share at the regional-industry level $x$, the regression covariate is given by $x_{i l t}$.

The dependent variable is the natural logarithm of average earnings in industry $i$ in state $l$ in time $t, w_{i l t}$. The measure of average earnings used is based on "total wage income" of employees in USD. Log earnings are used because these earnings data follows an approximately log-normal distribution.

The independent variable of interest is the macroeconomic demand relevant to the industry. One measure of this demand is the net hiring flow of workers into jobs. This flow measure is created from our data within each industry-region, ilt. To calculate the net hiring flow we take the number of new employment hires, $h$, minus the number of employment terminations, $r$, and then normalise this difference to account for industry size $n$. The new employment hires variable, $h$, is a count of the number of new hires recorded with job tenure of less than one year. The fires/redundancies variable, $r$, is a count of the number of workers experiencing employment terminations due to company closure, dismissal, mutual agreement, or end of contract. Equation 6 provides further detail for the construction of the macroeconomic demand variable:

$$
d_{i l t}=\frac{\left(h_{i l t}-r_{i l t}\right)}{n_{i l t}}
$$

Additional variables capturing human capital characteristics are included in Eq. 5. These include the ratio of male to female employees, $m$, the ratio of university to nonuniversity educated employees, $e$, and the age ratios, $\mathbf{a}$, for three age bands; below 25 years of age, 25 to 45 and 46 and above. Two age ratio dummy variables are included capturing ages 15-24 and 25-44 respectively (i.e. the omitted category is workers aged 45 or over).

A number of variables are also entered in the regression, which capture a number of structural characteristics of the industry. The share of workers in a regional industry that work in full-time permanent positions is captured by the variable $p$. The variable $n$ represents the number (count) of workers in each regional industry. As long as there is a positive amount of unemployment in the economy, $n$ may also be considered a demand-side characteristic. The specification controls for union coverage of the workers within an industry, $u{ }^{1}$ Finally, dummy variables for year $\left(\tau_{t}\right)$, industry $\left(\mathbf{I}_{i}\right)$ and state $\left(\mathbf{L}_{l}\right)$ are included in the full specification of the model. Time dummy variables account for any time trends or changes in survey methodology and industry dummy variables are also added to some specifications in order to account for persistent features of particular industrial wage structures. State dummy variables absorb any persistent earnings differentials across states including important variation in the industrial structure varies across states.

The regressions are weighted with the employment counts in each regional industry cell so that the results are representative of the employment distribution in the

\footnotetext{
${ }^{1}$ In the ASEC, individuals are asked if they are members or otherwise covered by a union agreement
} 
micro data. Because the data are collapsed to the regional industry level, the error structure accounts for arbitrary correlation within industry and region. ${ }^{2}$

The identification strategy in this paper circumvents the individual heterogeneity among workers and firms by averaging the data over region, time and two-digit industry, in line with Abowd et al. (2012). This allows the identification of changes in average wages of workers in industry groups with data that is purged of the differences in human capital within regional industry groups. This mitigates the complicating factors including self-selection into industries based on some unobserved characteristics, such as individual ability. Because firm characteristics are also absorbed into the regional industry averages, firm-specific factors such as efficiency wage setting (Borjas and Ramey 2000; Du Caju et al. 2010) are also circumvented. Finally, the inclusion of industry fixed effects may capture some additional sources of wage variation at the industry level. These sources might include whether or not minimum wages are a binding constraint in some industries compared to others, whether certain industries have a higher share of occupations which pay more, industryspecific market power (Abowd et al. 2012), and the exposure of certain industries to trade openness (Goldberg and Pavcnik 2005a; Amiti and Davis 2012). ${ }^{3}$

In general, the literature has abstracted from investigating the effects of the macroeconomic demand relevant to the industry on the industry average pay. This reflects both the difficulty of empirically approximating the level of demand relevant to the industry and the lack of relevant information in the large-scale surveys which are normally designed to capture only human capital variables. This paper adopts a methodology that provides the theoretical underpinnings for the level of macroeconomic demand relevant to the industry.

This paper uses two proxies capturing the industry demand for labour in the tradition of the search theory (Holt 1969, 1970; Modigliani and Tarantelli 1973; Fazzari et al. 1998). The first proxy is the net hiring flow of workers into jobs within a particular state and industry, outlined in Eq. 6 above. Because there is considerable detail in the industry measure (26 different 2-digit industry codes are available), this measure provides a substantial amount of cross-sectional variation. Respondents in the ASEC data are linked year-to-year so that new-hires and recent involuntary separations (redundancies) are observed. Because of a change in the unique identifier in 2005, the 2005 value is imputed by linear extrapolation (however, estimates omitting 2005 produced very similar results).

\footnotetext{
${ }^{2}$ Some heteroskedasticity may be introduced in this procedure. This issue is considered of secondary importance to the benefits of accounting for any potential group structure in the residuals within industry and region (Angrist and Pischke 2009). However, a weakness of this specification is that there are several cells (unique combination of industry, year and state) with no data that occur randomly. This is to be expected since not all states, in all years, should be expected to have persons surveyed in all industries. A close investigation showed that there are no states, industries or years where all data is missing. Only two industries (entertainment \& recreation and Finance, Banking and business services) have a relatively significant number of empty cells. However, this should not be expected to have any harmful impact on the validity of the results.

${ }^{3}$ Kambourov and Manovskii (2009) found that human capital is specific to the occupation rather than the industry.
} 
The second proxy is the job opening rate, or job vacancy rate, obtained from the Job Openings and Labour Turnover Survey (JOLTS). ${ }^{4}$ The number of job vacancies is considered in the literature to be a key indicator of excess demand for labour in the economy. One potential advantage of this measure is that, instead of varying across states and industries, this measure varies across industries at the national level. This may be favourable for capturing more precisely the aggregate demand pertaining to particular industries. In the analysis that follows industry codes are grouped in 9 industrial groups. This allows the harmonisation of the industry codes between the JOLTS and ASEC data. These industries are outlined in Appendix Table 8.

The two proxies of macroeconomic demand are not identical and therefore they should not be expected to have identical effects on industrial earning and hence industry earnings differentials. Because each is an approximation of the level of macroeconomic demand, estimation using both measures is important to demonstrate the robustness of the main result to particular sources of measurement error. For example, the net hiring flow measure is generated from population (worker) surveys and so captures actual worker movements. It cannot account for vacant positions that remain unfilled and is based only on sampled workers. The vacancy data are obtained from establishment surveys and capture firms' intentions to hire. These data cannot account for speculative vacancies or labour hoarding behaviour. If there are errors in the measurement in these proxy variables, the estimates may suffer from the classical errors in variables problem suggesting that the OLS estimates would be biased towards zero.

Under the simplifying assumption that every newly employed person fills a single job vacancy, the number of new hires equals the number of job vacancies that are filled in a given period, less the number of quits and redundancies. When this assumption does not hold, the impact of the two demand proxies may differ in timing and intensity. First, firms may hire several months after posting a vacancy. Second, external factors such as an improvement in business confidence may cause a reevaluation of hiring and firing intentions. This is reflected into realised hires and fires with some delay. Hiring rates might be influenced by a range of other factors beyond the control of any one firm, including the aggregate job matching and separation rates or the labour force participation rate. ${ }^{5}$ Overall, one should expect that when macroeconomic demand increases (decreases), the level of vacancies generally increases (falls), which in turn tends to lead to increased hiring (less hiring /increase in redundancy rates).

\footnotetext{
${ }^{4}$ These data are available in monthly series at the national level for 16 2-digit industry codes (excluding agriculture) for the years 2001-2013. This paper uses the March vacancy rates, which correspond to the month during which the ASEC survey is conducted.

${ }^{5}$ Population growth could also affect hiring rates through influence on the size of the labor market. However, population dynamics evolve quite slowly and would not be expected to influence the measured effects of demand on earnings presented in our analysis.
} 


\section{The Determination of Industry Earnings: OLS Estimates}

The preferred regression results based on Eq. 5 are shown in Tables 2 and 3. Specifications shown include different combinations of time, state and one-digit industry dummy variables that capture fundamental differences across sectors of the economy. Year-specific effects capture labour market policy changes.

From the point of view of this study it is important to note that both macroeconomic demand proxies exhibit a strong positive and statistically significant effect on the average earnings of industry by state. For instance, in the preferred specification in Column (5), Table 2, conditional on worker and firm characteristics, the coefficient of 0.72 suggests that for each unit increase in net hiring flow in industry by state increases the log of average industry earnings by state by 0.72 . The interpretation is that each $1 \%$ increase in demand in this ilt cell leads to approximately a 7.2 percent increase in wages. ${ }^{6}$ Similarly, when the national level industry-specific job vacancy rate is used as a proxy of macroeconomic demand in column (5) of Table 3, it is revealed that an increase in the vacancy rate above the national average of 1 percentage point leads to an increase in the log of average earnings by industry and state by 0.08 (approximately an 8 percent increase in earnings). Standard errors are clustered at the industry level because this is the source of variation for the vacancy rate. The estimate is statistically significant at the $1 \%$ level. $^{7}$

These estimates suggest that wages respond strongly to aggregate demand. A strong response may be expected because the estimates capture industry and statespecific wage responses to industry and state-specific demand. Raw aggregated data show wage increases that are more than proportional with respect to employment, even in industries where wage growth has been lacklustre in recent decades. For example, from January 2010 to January 2011 US manufacturing employment rose one percentage point while average earnings in the same industry rose by two percent. $^{8}$ Although there are no comparable studies in the literature to which to which the above estimates can be compared, Beeson et al. (2001) attribute substantial losses in steelworker wages (20\%) to changes in the demand for steel during the 1980s.

The above findings provide convincing evidence that aggregate demand factors across industries have significant and important effects on relative earnings. It is

\footnotetext{
${ }^{6}$ The net hiring flow variable is normalised by the number of workers in an industry, $n_{i l t}$. Thus, a single unit change in this variable, reflected in the coefficient, amounts to a $100 \%$ increase in employment in industry $i$ in state $l$ during year $t$. A $1 \%$ increase is thus found by dividing $\beta_{1} / 100$.

${ }^{7}$ Because cluster-robust standard errors may not satisfy the asymptotic assumptions when the number of clusters is small, a cluster-robust wild bootstrap procedure is used to provide p-values that satisfy these assumptions (Cameron et al. 2008). This procedure validates the initial results. The $p$-values are reported at the bottom of Tables 2 and 3.

${ }^{8}$ Authors' calculations using data from the Federal Reserve Bank of St. Louis: "U.S. Bureau of Labor Statistics, Average Hourly Earnings of All Employees: Manufacturing [CES3000000003]" for earnings and "U.S. Bureau of Labor Statistics, All Employees, Manufacturing [MANEMP]" for employment. Data accessed Dec 27, 2019.
} 
Table 2 OLS estimates: industry wage differentials in the US 1997-2013

\begin{tabular}{|c|c|c|c|c|c|}
\hline & $\begin{array}{l}\text { (1) } \\
\ln w_{i \ell t}\end{array}$ & $\begin{array}{l}\text { (2) } \\
\ln w_{i \ell t}\end{array}$ & $\begin{array}{l}(3) \\
\ln w_{i \ell t}\end{array}$ & $\begin{array}{l}\text { (4) } \\
\ln w_{i \ell t}\end{array}$ & $\begin{array}{l}\text { (5) } \\
\ln w_{i \ell t}\end{array}$ \\
\hline \multicolumn{6}{|l|}{ Demand (D) } \\
\hline Net hiring flow & $\begin{array}{l}0.744 * * * \\
(0.281)\end{array}$ & $\begin{array}{l}0.770 * * * \\
(0.283)\end{array}$ & $\begin{array}{l}0.497 * * \\
(0.230)\end{array}$ & $\begin{array}{l}1.062 * * * \\
(0.260)\end{array}$ & $\begin{array}{l}0.721 * * * \\
(0.203)\end{array}$ \\
\hline \multicolumn{6}{|l|}{ Person $(\overline{\mathbf{P}})$} \\
\hline Share Male & $\begin{array}{l}0.269 * * \\
(0.129)\end{array}$ & $\begin{array}{l}0.284 * * \\
(0.122)\end{array}$ & $\begin{array}{l}0.198 \\
(0.135)\end{array}$ & $\begin{array}{l}0.279 * * * \\
(0.089)\end{array}$ & $\begin{array}{l}0.251 * * * \\
(0.090)\end{array}$ \\
\hline Share University Ed. & $\begin{array}{l}0.712 * * * \\
(0.172)\end{array}$ & $\begin{array}{l}0.718^{* * * *} \\
(0.171)\end{array}$ & $\begin{array}{l}0.574 * * * \\
(0.174)\end{array}$ & $\begin{array}{l}0.661 * * * \\
(0.150)\end{array}$ & $\begin{array}{l}0.438 * * * \\
(0.149)\end{array}$ \\
\hline Share age $<25$ & $\begin{array}{l}-0.795^{* * *} \\
(0.114)\end{array}$ & $\begin{array}{l}-0.843^{* * *} \\
(0.116)\end{array}$ & $\begin{array}{l}-0.732 * * * \\
(0.120)\end{array}$ & $\begin{array}{l}-0.916^{* * * *} \\
(0.080)\end{array}$ & $\begin{array}{l}-0.751 \text { *** } \\
(0.075)\end{array}$ \\
\hline Share age $25-45$ & $\begin{array}{l}-0.040 \\
(0.063)\end{array}$ & $\begin{array}{l}-0.062 \\
(0.063)\end{array}$ & $\begin{array}{l}-0.017 \\
(0.060)\end{array}$ & $\begin{array}{l}-0.110^{*} \\
(0.058)\end{array}$ & $\begin{array}{l}-0.058 \\
(0.054)\end{array}$ \\
\hline \multicolumn{6}{|l|}{$\operatorname{Firm}(\overline{\mathbf{F}})$} \\
\hline Share full-time & $\begin{array}{l}1.017 * * * \\
(0.106)\end{array}$ & $\begin{array}{l}1.029 * * * \\
(0.112)\end{array}$ & $\begin{array}{l}1.113 * * * \\
(0.105)\end{array}$ & $\begin{array}{l}0.901 * * * \\
(0.059)\end{array}$ & $\begin{array}{l}1.014 * * * \\
(0.068)\end{array}$ \\
\hline Union share & $\begin{array}{l}0.025 \\
(0.024)\end{array}$ & $\begin{array}{l}0.010 \\
(0.023)\end{array}$ & $\begin{array}{l}-0.075^{* *} \\
(0.038)\end{array}$ & $\begin{array}{l}0.054 * \\
(0.032)\end{array}$ & $\begin{array}{l}-0.043 \\
(0.027)\end{array}$ \\
\hline Share firm size $<10$ & $\begin{array}{l}-0.289^{* *} \\
(0.128)\end{array}$ & $\begin{array}{l}-0.272^{* *} \\
(0.121)\end{array}$ & $\begin{array}{l}-0.339^{* *} \\
(0.144)\end{array}$ & $\begin{array}{l}-0.261 * * * \\
(0.099)\end{array}$ & $\begin{array}{l}-0.321 * * * \\
(0.097)\end{array}$ \\
\hline Share firm size $10-99$ & $\begin{array}{l}-0.093 \\
(0.095)\end{array}$ & $\begin{array}{l}-0.085 \\
(0.096)\end{array}$ & $\begin{array}{l}-0.124 \\
(0.099)\end{array}$ & $\begin{array}{l}-0.027 \\
(0.086)\end{array}$ & $\begin{array}{l}-0.123^{*} \\
(0.074)\end{array}$ \\
\hline Employment & & $\begin{array}{l}0.021^{* *} \\
(0.009)\end{array}$ & $\begin{array}{l}-0.008 \\
(0.013)\end{array}$ & $\begin{array}{l}0.022 * * \\
(0.010)\end{array}$ & $\begin{array}{l}-0.014 * * * \\
(0.006)\end{array}$ \\
\hline \multicolumn{6}{|l|}{ Industry dummy variables } \\
\hline Agriculture/Mining/Forestry & & & & $\begin{array}{l}0.292 * * * \\
(0.028)\end{array}$ & $\begin{array}{l}0.319 * * * \\
(0.029)\end{array}$ \\
\hline Construction & & & & $\begin{array}{l}0.009 \\
(0.052)\end{array}$ & $\begin{array}{l}0.013 \\
(0.055)\end{array}$ \\
\hline Transp./Trade/Utilities & & & & $\begin{array}{l}0.036 \\
(0.049)\end{array}$ & $\begin{array}{l}0.044 \\
(0.047)\end{array}$ \\
\hline Fin./Banking/Bus. Service & & & & $\begin{array}{l}0.123 * * \\
(0.059)\end{array}$ & $\begin{array}{l}0.126^{* * *} \\
(0.059)\end{array}$ \\
\hline Pers. Service incl. Hlth & & & & $\begin{array}{l}0.053 \\
(0.110)\end{array}$ & $\begin{array}{l}0.121 \\
(0.091)\end{array}$ \\
\hline Entertainment/Recreation & & & & $\begin{array}{l}-0.059 \\
(0.065)\end{array}$ & $\begin{array}{l}-0.084 \\
(0.060)\end{array}$ \\
\hline Professional services & & & & $\begin{array}{l}0.128 * * \\
(0.053)\end{array}$ & $\begin{array}{l}0.183 * * * \\
(0.050)\end{array}$ \\
\hline
\end{tabular}


Table 2 (continued)

\begin{tabular}{llllll}
\hline & $(1)$ & $(2)$ & $(3)$ & $(4)$ & $(5)$ \\
& $\ln w_{i \ell t}$ & $\ln w_{i \ell t}$ & $\ln w_{i \ell t}$ & $\ln w_{i \ell t}$ & $\ln w_{i \ell t}$ \\
\hline Public administration & & & & $0.223 * * *$ & $0.214 * * *$ \\
& & & $(0.082)$ & $(0.065)$ \\
Constant & $8.961 * * *$ & $8.898 * * *$ & $9.154 * * *$ & $8.924 * * *$ & $9.162 * * *$ \\
& $(0.278)$ & $(0.286)$ & $(0.228)$ & $(0.217)$ & $(0.182)$ \\
Year dummy variables & YES & YES & YES & YES & YES \\
State dummy variables & NO & NO & YES & NO & YES \\
Observations & 10,993 & 10,993 & 10,993 & 10,993 & 10,993 \\
R-squared & 0.776 & 0.778 & 0.811 & 0.797 & 0.828 \\
F IND & & & & 333.9 & 276.5 \\
wboot P & 0.000 & 0.000 & 0.021 & 0.001 & 0.001 \\
\hline
\end{tabular}

Source: March CPS, 1997-2013. Number of fires per state-industry, used in net hiring flow measure, imputed in 2005 with linear interpolation since data linkage issues prevent consistent observation of lagged labor market status in this year. Net hiring flow is the number of hires - fires observed in the linked longitudinal sample. Standard errors clustered by cell are robust to heteroskedasticity and arbitrary serial correlation within industry. $* * * \mathrm{p}<0.01, * * \mathrm{p}<0.05, * \mathrm{p}<0.1$. Omitted industry dummy variable is Manufacturing. Employment measured per 100 million. F IND is F-test for joint significance of industry dummy variables

worth highlighting that the above effects are in addition to the premium paid to larger industries captured by $\beta_{7}$. Industry size, as measured by the share of the national labour force it employs, has separate effects on industry average earnings that may reflect a baseline demand for labour over the long term. Instead, the above estimates of $\beta_{1}$ suggest that firms within regional industries characterised by high demand may attempt to attract labour from across the industrial distribution or from neighbouring states by offering higher wages. Where firms seek to attract workers employed in different fields of expertise a wage premium may be necessary to induce a worker to leave a job where they currently enjoy a return to their specific human capital.

The remaining independent control variables have the expected effect on average earning. Human capital factors are shown to affect industrial average wages by state. The coefficient for the male-female ratio is positive and significant. The traditional reasons explaining the gender wage gap range from differences in human capital, occupational sorting and discrimination (Gannon et al. (2005) for Europe and Blau and Kahn (2006) for the US). Unsurprisingly, the higher the proportion of university educated workers in a particular industry, the higher are the average earnings in that industry. These results are consistent with a substantial and robust return to human capital investment for US workers. Card (1999) surveys this literature and suggests that causal estimates may be close to $10 \%$ per year of education. Industries dominated by younger workers have significantly lower average earnings in comparison to those with higher shares of workers aged forty-five or above. This estimate is consistent with the larger body of literature stemming from Mincer (1974) demonstrating the importance of controlling for experience in the estimation of earnings. 
Table 3 OLS estimates: Industry Wage Differentials in the US 2001-2013

\begin{tabular}{|c|c|c|c|c|c|}
\hline & $\begin{array}{l}(1) \\
\ln w_{i \ell t}\end{array}$ & $\begin{array}{l}(2) \\
\ln w_{i \ell t}\end{array}$ & $\begin{array}{l}(3) \\
\ln w_{i \ell t}\end{array}$ & $\begin{array}{l}\text { (4) } \\
\ln w_{i \ell t}\end{array}$ & $\begin{array}{l}\text { (5) } \\
\ln w_{i \ell t}\end{array}$ \\
\hline \multicolumn{6}{|l|}{ Demand (D) } \\
\hline Vacancy rate & $\begin{array}{l}0.085 * * * \\
(0.028)\end{array}$ & $\begin{array}{l}0.086 * * * \\
(0.027)\end{array}$ & $\begin{array}{l}0.065^{* * *} * \\
(0.020)\end{array}$ & $\begin{array}{l}0.107 * * * \\
(0.023)\end{array}$ & $\begin{array}{l}0.079 * * * \\
(0.014)\end{array}$ \\
\hline \multicolumn{6}{|l|}{ Person $(\overline{\mathbf{P}})$} \\
\hline Share male & $\begin{array}{l}0.450 * * * \\
(0.109)\end{array}$ & $\begin{array}{l}0.467 * * * \\
(0.104)\end{array}$ & $\begin{array}{l}0.328 * * * \\
(0.112)\end{array}$ & $\begin{array}{l}0.267 * * \\
(0.112)\end{array}$ & $\begin{array}{l}0.249 * * \\
(0.111)\end{array}$ \\
\hline Share University Ed. & $\begin{array}{l}0.683 * * * \\
(0.152)\end{array}$ & $\begin{array}{l}0.686^{* * * *} \\
(0.151)\end{array}$ & $\begin{array}{l}0.545^{* * *} \\
(0.150)\end{array}$ & $\begin{array}{l}0.721 * * * \\
(0.133)\end{array}$ & $\begin{array}{l}0.468 * * * \\
(0.126)\end{array}$ \\
\hline Share Age $<25$ & $\begin{array}{l}-0.646^{* * * *} \\
(0.124)\end{array}$ & $\begin{array}{l}-0.690 * * * \\
(0.130)\end{array}$ & $\begin{array}{l}-0.626^{* * * *} \\
(0.124)\end{array}$ & $\begin{array}{l}-0.815^{* * *} \\
(0.086)\end{array}$ & $\begin{array}{l}-0.662^{* * *} \\
(0.073)\end{array}$ \\
\hline Share Age $25-45$ & $\begin{array}{l}0.091 \\
(0.094)\end{array}$ & $\begin{array}{l}0.074 \\
(0.096)\end{array}$ & $\begin{array}{l}0.075 \\
(0.079)\end{array}$ & $\begin{array}{l}0.042 \\
(0.087)\end{array}$ & $\begin{array}{l}0.054 \\
(0.063)\end{array}$ \\
\hline \multicolumn{6}{|l|}{ Firm $(\overline{\mathbf{F}})$} \\
\hline Share full-time & $\begin{array}{l}0.969 * * * \\
(0.089)\end{array}$ & $\begin{array}{l}0.980 * * * \\
(0.097)\end{array}$ & $\begin{array}{l}1.086^{* * *} \\
(0.086)\end{array}$ & $\begin{array}{l}0.834 * * * \\
(0.075)\end{array}$ & $\begin{array}{l}0.960 * * * \\
(0.074)\end{array}$ \\
\hline Union share & $\begin{array}{l}-0.011 \\
(0.044)\end{array}$ & $\begin{array}{l}-0.027 \\
(0.043)\end{array}$ & $\begin{array}{l}-0.100^{* * * *} \\
(0.036)\end{array}$ & $\begin{array}{l}0.031 \\
(0.043)\end{array}$ & $\begin{array}{l}-0.064^{* *} \\
(0.028)\end{array}$ \\
\hline Share firm size $<10$ & $\begin{array}{l}-0.411^{* * *} \\
(0.121)\end{array}$ & $\begin{array}{l}-0.393^{* * *} \\
(0.113)\end{array}$ & $\begin{array}{l}-0.458^{* * * *} \\
(0.147)\end{array}$ & $\begin{array}{l}-0.291^{* * * *} \\
(0.093)\end{array}$ & $\begin{array}{l}-0.372^{* * *} \\
(0.088)\end{array}$ \\
\hline Share firm size 10-99 & $\begin{array}{l}-0.064 \\
(0.106)\end{array}$ & $\begin{array}{l}-0.053 \\
(0.107)\end{array}$ & $\begin{array}{l}-0.117 \\
(0.110)\end{array}$ & $\begin{array}{l}-0.035 \\
(0.074)\end{array}$ & $\begin{array}{l}-0.151^{* *} \\
(0.064)\end{array}$ \\
\hline Employment & & $\begin{array}{l}0.020 * * \\
(0.009)\end{array}$ & $\begin{array}{l}-0.011 \\
(0.014)\end{array}$ & $\begin{array}{l}0.018 * * \\
(0.008)\end{array}$ & $\begin{array}{l}-0.026^{* * *} \\
(0.006)\end{array}$ \\
\hline \multicolumn{6}{|l|}{ Industry dummy variables } \\
\hline Agriculture/Mining/Forestry & & & & $\begin{array}{l}0.287 * * * \\
(0.035)\end{array}$ & $\begin{array}{l}0.310 * * * \\
(0.032)\end{array}$ \\
\hline Construction & & & & $\begin{array}{l}-0.012 \\
(0.059)\end{array}$ & $\begin{array}{l}0.001 \\
(0.058)\end{array}$ \\
\hline Transp./Trade/Utilities & & & & $\begin{array}{l}-0.037 \\
(0.048)\end{array}$ & $\begin{array}{l}-0.006 \\
(0.042)\end{array}$ \\
\hline Fin./Banking/Bus. Service & & & & $\begin{array}{l}-0.051 \\
(0.077)\end{array}$ & $\begin{array}{l}-0.002 \\
(0.064)\end{array}$ \\
\hline Pers. Service incl. Hlth & & & & $\begin{array}{l}-0.166^{*} \\
(0.091)\end{array}$ & $\begin{array}{l}-0.023 \\
(0.076)\end{array}$ \\
\hline Entertainment/Recreation & & & & $\begin{array}{l}-0.268^{* * * *} \\
(0.095)\end{array}$ & $\begin{array}{l}-0.245^{* * *} \\
(0.073)\end{array}$ \\
\hline Professional services & & & & $\begin{array}{l}-0.006 \\
(0.050)\end{array}$ & $\begin{array}{l}0.089 * * \\
(0.043)\end{array}$ \\
\hline
\end{tabular}


Table 3 (continued)

\begin{tabular}{|c|c|c|c|c|c|}
\hline & (1) & (2) & (3) & (4) & (5) \\
\hline & $\ln w_{i \ell t}$ & $\ln w_{i \ell t}$ & $\ln w_{i \ell t}$ & $\ln w_{i \ell t}$ & $\ln w_{i \ell t}$ \\
\hline \multirow[t]{2}{*}{ Public administration } & & & & -0.009 & 0.060 \\
\hline & & & & $(0.048)$ & $(0.045)$ \\
\hline \multirow[t]{2}{*}{ Constant } & $9.328 * * *$ & $9.286^{* * * *}$ & $9.371 * * *$ & $9.525 * * *$ & $9.499 * * *$ \\
\hline & $(0.170)$ & $(0.176)$ & $(0.129)$ & $(0.091)$ & $(0.098)$ \\
\hline Year dummy variables & YES & YES & YES & YES & YES \\
\hline State dummy variables & $\mathrm{NO}$ & NO & YES & NO & YES \\
\hline Observations & 8,883 & 8,883 & 8,883 & 8,883 & 8,883 \\
\hline $\mathrm{R}$-squared & 0.765 & 0.768 & 0.809 & 0.785 & 0.826 \\
\hline F IND & & & & 1482.5 & 3399.5 \\
\hline w boot P & 0.011 & 0.011 & 0.018 & 0.007 & 0.000 \\
\hline
\end{tabular}

Source: March CPS and JOLTS, 2001-2013. Standard errors clustered by cell are robust to heteroskedasticity and arbitrary serial correlation within industry. $* * * \mathrm{p}<0.01, * * \mathrm{p}<0.05, * \mathrm{p}<0.1$. Omitted industry dummy variable is Manufacturing. Employment measured per 100 million. F IND is F-test for joint significance of industry dummy variables

Several labour market characteristics that vary across industry and state are also important contributors to average earnings. An increase in share of full-time workers in a regional industry relative to the national average, would increase the log of average earnings by industry. The reasons for this may be twofold. Not only do fulltime employees work more hours than part-time and temporary employees but also full-time employees may be more likely to receive training that improves productivity and wages (see Hirsch (2005) for a summary of the literature). Industries with a high concentration of smaller firms also tend to have lower average earnings. A considerable body of literature beginning with Moore (1911) shows that larger firms pay higher wages. The survey by Oi and Idson (1999) suggests that firm size effects are similar in size to the gender wage gap. Surprisingly, higher union coverage by industry appears to be associated with lower pay but this might reflect reverse causality as industries with lower average pay tend to be more fertile for union activity. ${ }^{9}$

\section{The Importance of Macroeconomic Demand Relevant to the Industry}

In this section a further attempt is made to establish the relative importance of worker characteristics, firm characteristics, and demand factors. In doing so the study compares several specifications which might be used to explain wage differentials across industries in order detailed in Table 4. The specifications in Column (1), (4) and (7) do not include the relevant proxies of the macroeconomic demand relevant to the

\footnotetext{
${ }^{9}$ Note that endogeneity is not considered for the effect of union coverage on pay relationship as trade union coverage is a control variable in this paper.
} 


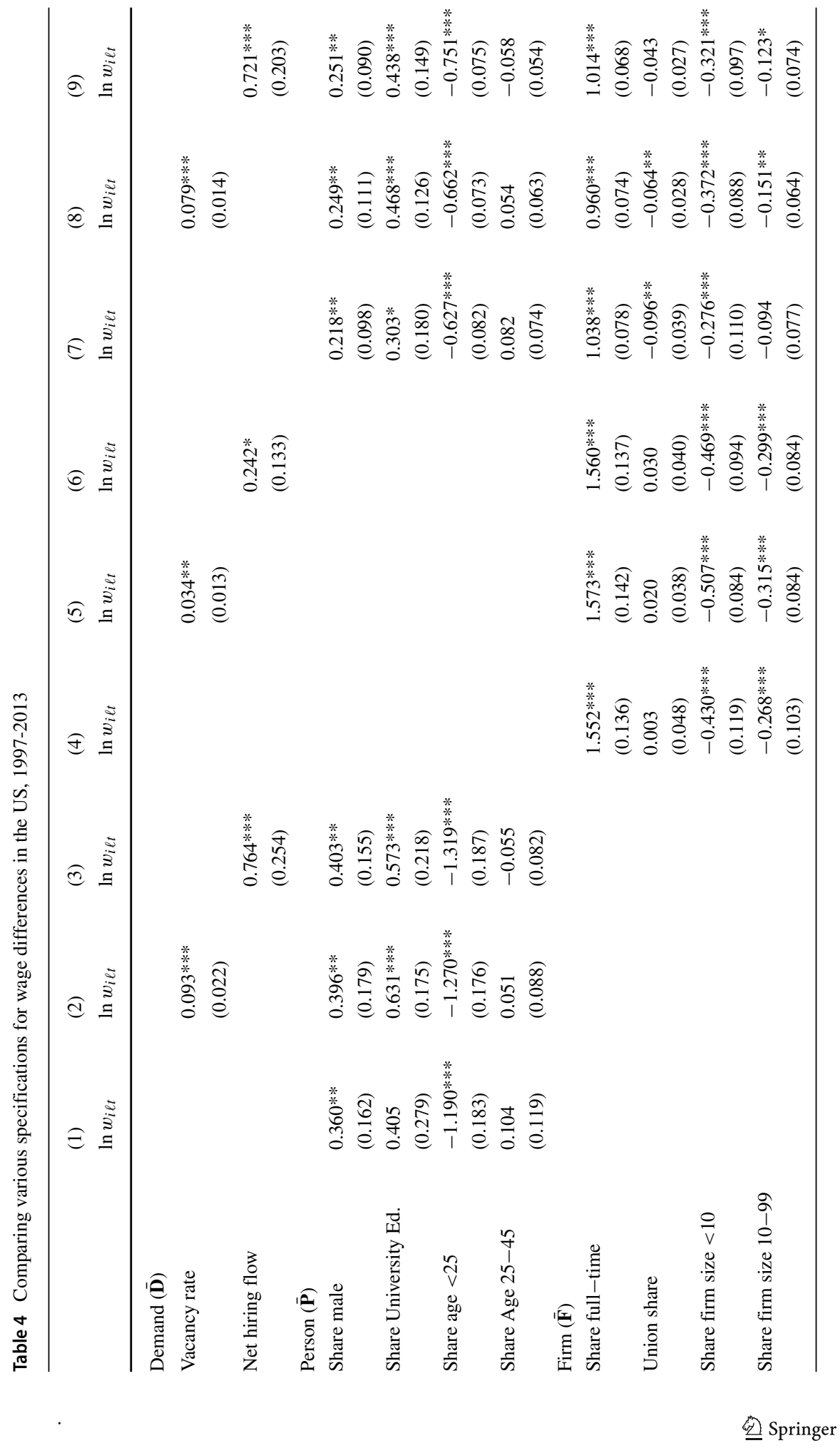




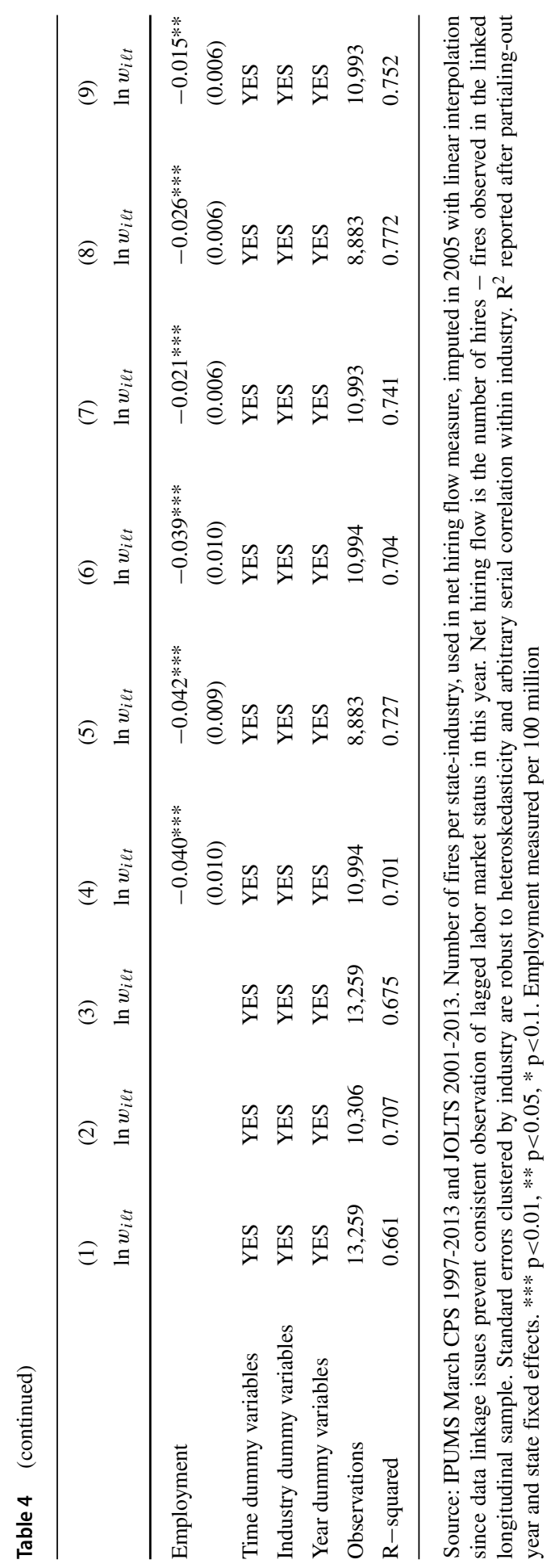


Table 5 Robustness to time period: before and after the great recession

\begin{tabular}{|c|c|c|c|c|}
\hline & \multicolumn{2}{|c|}{$\begin{array}{l}\text { Net hiring flow } \\
\text { Demand measure }\end{array}$} & \multicolumn{2}{|c|}{$\begin{array}{l}\text { Vacancy rate } \\
\text { Demand measure }\end{array}$} \\
\hline & $\begin{array}{l}1997-2007 \\
\ln w_{i \ell t}\end{array}$ & $\begin{array}{l}2008-2013 \\
\ln w_{i \ell t}\end{array}$ & $\begin{array}{l}2001-2007 \\
\ln w_{i \ell t}\end{array}$ & $\begin{array}{l}2008-2013 \\
\ln w_{i \ell t}\end{array}$ \\
\hline Demand (D) & $\begin{array}{l}0.681 * * * \\
(0.229)\end{array}$ & $\begin{array}{l}1.085 * * * \\
(0.186)\end{array}$ & $\begin{array}{l}0.076 * * * \\
(0.016)\end{array}$ & $\begin{array}{l}0.103 * * * \\
(0.018)\end{array}$ \\
\hline \multicolumn{5}{|l|}{ Person $(\overline{\mathbf{P}})$} \\
\hline Share male & $\begin{array}{l}0.238 * * * \\
(0.091)\end{array}$ & $\begin{array}{l}0.307 * * * \\
(0.082)\end{array}$ & $\begin{array}{l}0.243 * * \\
(0.113)\end{array}$ & $\begin{array}{l}0.265 * * \\
(0.114)\end{array}$ \\
\hline Share University Ed & $\begin{array}{l}0.408 * * \\
(0.162)\end{array}$ & $\begin{array}{l}0.505 * * * \\
(0.131)\end{array}$ & $\begin{array}{l}0.490 * * * \\
(0.132)\end{array}$ & $\begin{array}{l}0.488^{* * * *} \\
(0.112)\end{array}$ \\
\hline Share age $<25$ & $\begin{array}{l}-0.762^{* * * *} \\
(0.072)\end{array}$ & $\begin{array}{l}-0.803^{* * * *} \\
(0.080)\end{array}$ & $\begin{array}{l}-0.705^{* * *} \\
(0.070)\end{array}$ & $\begin{array}{l}-0.603 * * * \\
(0.085)\end{array}$ \\
\hline Share age $25-45$ & $\begin{array}{l}-0.029 \\
(0.048)\end{array}$ & $\begin{array}{l}-0.117 * * \\
(0.058)\end{array}$ & $\begin{array}{l}0.047 \\
(0.067)\end{array}$ & $\begin{array}{l}0.033 \\
(0.069)\end{array}$ \\
\hline \multicolumn{5}{|l|}{ Firm $(\overline{\mathbf{F}})$} \\
\hline Share full-time & $\begin{array}{l}0.952 * * * \\
(0.066)\end{array}$ & $\begin{array}{l}1.005 * * * \\
(0.070)\end{array}$ & $\begin{array}{l}0.893 * * * \\
(0.067)\end{array}$ & $\begin{array}{l}1.031 \text { *** } \\
(0.079)\end{array}$ \\
\hline Union share & $\begin{array}{l}-0.058 \\
(0.036)\end{array}$ & $\begin{array}{l}-0.008 \\
(0.021)\end{array}$ & $\begin{array}{l}-0.064 * * \\
(0.030)\end{array}$ & $\begin{array}{l}-0.056^{* *} \\
(0.029)\end{array}$ \\
\hline Share firm size $<9$ & $\begin{array}{l}-0.309 * * * \\
(0.096)\end{array}$ & $\begin{array}{l}-0.407 * * * \\
(0.092)\end{array}$ & $\begin{array}{l}-0.389 * * * \\
(0.086)\end{array}$ & $\begin{array}{l}-0.374 * * * \\
(0.101)\end{array}$ \\
\hline Share firm size 10-99 & $\begin{array}{l}-0.121^{*} \\
(0.071)\end{array}$ & $\begin{array}{l}-0.193 * * * \\
(0.071)\end{array}$ & $\begin{array}{l}-0.163 * * \\
(0.068)\end{array}$ & $\begin{array}{l}-0.137 * * \\
(0.069)\end{array}$ \\
\hline Employment & $\begin{array}{l}-0.024 * * * \\
(0.007)\end{array}$ & $\begin{array}{l}-0.015^{* * * *} \\
(0.006)\end{array}$ & $\begin{array}{l}-0.036^{* * * *} \\
(0.009)\end{array}$ & $\begin{array}{l}-0.021 * * * \\
(0.005)\end{array}$ \\
\hline Constant & $\begin{array}{l}8.911^{* * * *} \\
(0.254)\end{array}$ & $\begin{array}{l}8.626 * * * \\
(0.221)\end{array}$ & $\begin{array}{l}9.398 * * * \\
(0.094)\end{array}$ & $\begin{array}{l}9.386^{* * *} \\
(0.122)\end{array}$ \\
\hline State dummy variables & YES & YES & YES & YES \\
\hline Industry dummy variables & YES & YES & YES & YES \\
\hline Year dummy variables & YES & YES & YES & YES \\
\hline Observations & 6,978 & 4,015 & 4,868 & 4,015 \\
\hline R-squared & 0.806 & 0.821 & 0.814 & 0.815 \\
\hline
\end{tabular}

Source: March CPS, 1997-2013 and JOLTS 2001-2013. Number of fires per state-industry, used in net hiring flow measure, imputed in 2005 with linear interpolation since data linkage issues prevent consistent observation of lagged labor market status in this year. Net hiring flow is the number of hires - fires observed in the linked longitudinal sample. Standard errors clustered by cell are robust to heteroskedasticity and arbitrary serial correlation within industry. $* * * \mathrm{p}<0.01, * * \mathrm{p}<0.05, * \mathrm{p}<0.1$. Employment measured per 100 million

industry. Thus, by comparing specification (1) to specifications (2) and (3), and the specification (4) to specifications (5) and (6) it is evident that both demand proxies improve the explanatory power of the respective regressions. The most informative 
comparison is a comparison of the last three columns. Relative to specification (7), without any demand proxy, specification (8) shows that the vacancy rate explains an additional $3 \%$ of the variation in wages across regional industries. This is a statistically significant component of the wage in light of the richness of this specification. For example, the addition of time-varying workforce characteristics including age, gender and education, explains an additional $4 \%$ of the variation in wages across regional industries (comparing specifications (4) and (7)). The net hiring flow proxy is also able to explain an additional $1 \%$ of the variation in wages, conditional on worker and firm characteristics. In light of the differences in these two proxies, some discrepancy can be expected though both of them point towards a similar direction. The net hiring flow measure may contain more noise because it is constructed from survey data and this measure covers three additional years of data (1997-2000) when wages in the US grew more rapidly than in subsequent years.

\section{The Macroeconomic Demand Effects Over Time and Across Industries}

Interindustry wage differentials have been shown to be a permanent phenomenon (Krueger and Summers 1988). ${ }^{10}$ Thus, the study turns to investigate whether the contribution of macroeconomic demand to industrial average wages is also permanent. Two approaches are used. First, the samples are split at 2007/2008 and the models in Columns (8) and (9) of Table 4 are re-estimated before and after this year. The results appear in Table 5, and they show that that both the measures of demand have an important positive effect on industry wages throughout the sample period. To further demonstrate the robustness of our results to any particular time period, estimation of the above models is also performed on a 5-year moving sample window across the sample. The results are reported in Fig. 1. In general, they confirm that both the measures of demand have an important positive effect on industry wages. The size of the measured effect grows over time using both proxy variables, although there appears to be some structural break during the dot-com bubble in early 2000 s captured by the net hiring flow proxy for excess demand.

Although the above discussion shows the important effects of macroeconomic demand on the determination of wage differentials across industries it does not provide any indication of how this effect is distributed between industries. ${ }^{11}$ To illustrate this the models in Columns (8) and (9) of Table 4 are re-estimated adding a set of interactive terms for industry dummy variables and the demand proxies. These interactions decompose the demand effects by industry. Results are reported in Table 6. The effect of demand as reflected on the net hiring flow is significantly higher compared to its effect on Manufacturing in all industries with two exceptions: Agriculture/Mining/Forestry and Transport/Trade/Utilities. However, larger effects of demand relative to Manufacturing reflected on the vacancy proxy are found in

\footnotetext{
${ }^{10}$ The authors are grateful to an anonymous referee of this journal for this point.

${ }^{11}$ The authors are grateful to the Editor of this journal for this point.
} 

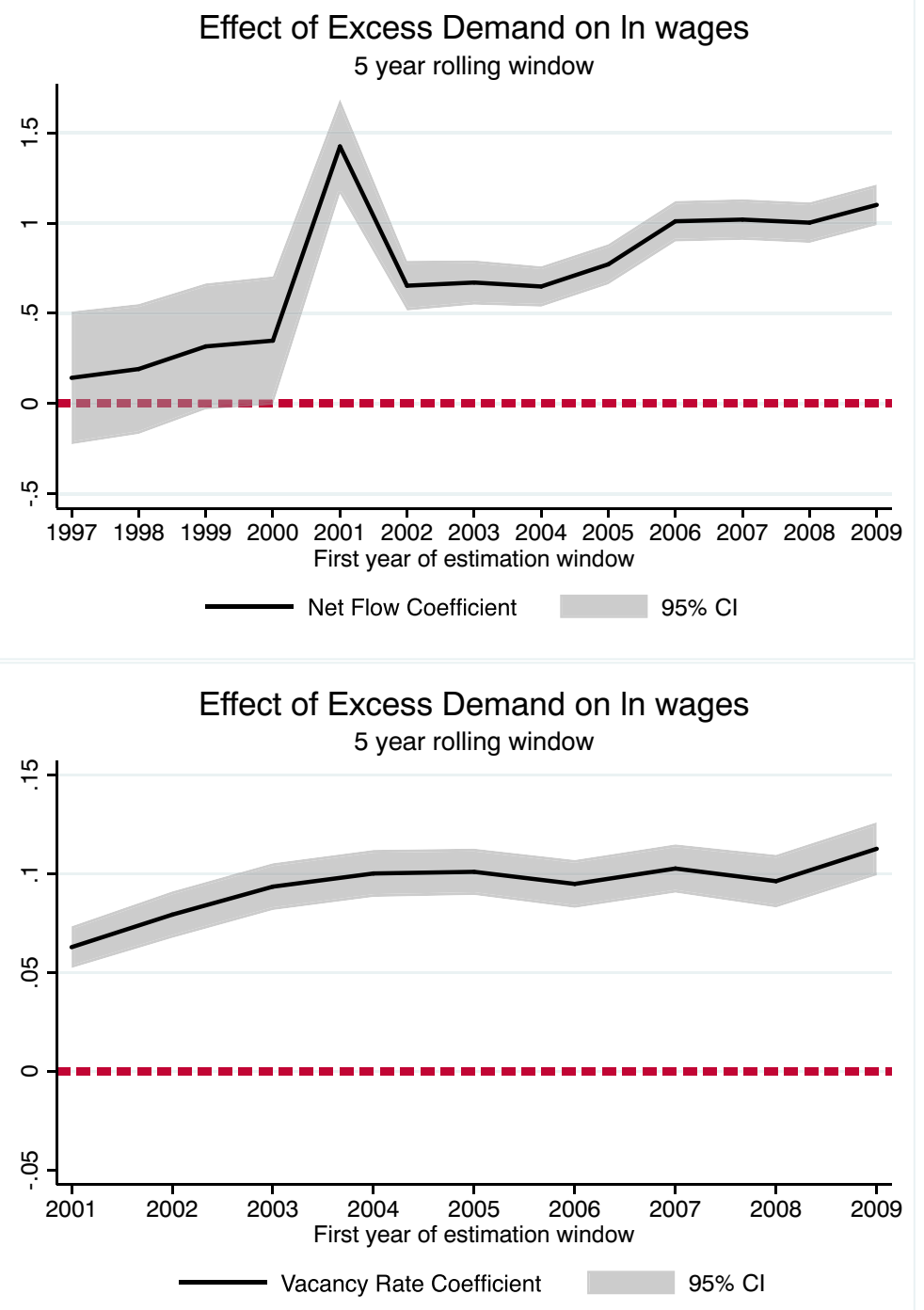

Fig. 1 Robustness to time period. Plots show coefficient estimates using a moving 5-year sample window. Specifications estimated are those presented in column (5) of Tables 2 and 3

Personal Services/Health and Professional Services industry. Agriculture is weakly positive but the effect is marginally significant.

\section{The Causal Effect of Demand on Industry Earnings: IV Estimates}

All the estimated models above suffer from the fact that although they establish the association between the dependant variable and the main variable of interest, 
Table 6 Decomposition of excess demand effects by industry

\begin{tabular}{|c|c|c|c|c|}
\hline & \multicolumn{2}{|c|}{ Net hiring flow measure } & \multicolumn{2}{|c|}{ Vacancy measure } \\
\hline & Coef. & SE & Coef. & SE \\
\hline$D \times$ Agriculture/Mining/Forestry & -0.146 & $(0.391)$ & $0.008 *$ & $(0.004)$ \\
\hline$D \times$ Construction & $0.801 * * *$ & $(0.177)$ & 0.018 & $(0.023)$ \\
\hline$D \times$ Transp./Trade/Utilities & 0.370 & $(0.398)$ & 0.014 & $(0.017)$ \\
\hline$D \times$ Fin./Banking/Bus. Service & $0.859 * * *$ & $(0.176)$ & -0.001 & $(0.010)$ \\
\hline$D \times$ Pers. Service incl. Hlth & $1.950 * * *$ & $(0.384)$ & $0.135^{* * *}$ & $(0.028)$ \\
\hline$D \times$ Entertainment/Recreation & $1.291 * * *$ & $(0.190)$ & 0.001 & $(0.012)$ \\
\hline$D \times$ Professional services & $1.110^{* * *}$ & $(0.162)$ & $0.049 * *$ & $(0.020)$ \\
\hline$D \times$ Public administration & $0.865^{* * *}$ & $(0.136)$ & 0.081 & $(0.078)$ \\
\hline $\mathrm{N}$ & 10,993 & & & 8,883 \\
\hline
\end{tabular}

Coefficients from regressions with interaction terms of industry and excess demand measure. Omitted industry is Manufacturing. Specifications estimated are those presented in column (5) of Tables 2 and 3 with the addition of interaction terms for industry dummy variables and the relevant demand measure

macroeconomic demand, they are unable to establish causality. This section uses an instrumental variables (IV) approach to investigate the causal effect of macroeconomic demand changes on industry wage differences. IV estimates can be expected to identify causal effects in the case where OLS are influenced by any potential bi-directional relationship between industry-average wages and macroeconomic demand that varies over time. Demand may be endogenous with respect to wages because increases in wages may lead to increases in consumer expenditure, thus increasing the demand for goods and services in the economy.

The instrument used in this paper exploits exogenous variation the demand for goods that is external to the US economy. The instrumental variable, $z$, is a prediction for the value of exports for the years 1997-2013 that would have occurred if industryshares of exports were fixed at 2001 levels. The instrument is constructed in Eq. 8 as:

$$
z_{i t}=Q_{t} \cdot Y_{i}
$$

where $Q_{t}$ is the aggregate time series for exports as a share of GDP for the years 1997-2013 taken from the Federal Reserve of St. Louis Economic Database. ${ }^{12}$ The variable $Y_{i}$ contains 2001 industrial shares of total exports in millions of USD from the Census Bureau and the Bureau of Economic Analysis. ${ }^{13}$

The exclusion restriction for this type of instrument is intuitive because $z$ is a counterfactual exports figure. Because shares are fixed at 2001 levels, $z$ does not allow

\footnotetext{
${ }^{12}$ Shares of gross domestic product: Exports of goods and services (B020RE1A156NBEA), Federal Reserve Bank of St. Louis, original sourced from US Bureau of Economic Analysis.

${ }^{13}$ Share of goods exported from the USA TRADE ONLINE database of the Census Bureau: Total commodity exports worldwide, valued in USD by NAICS industry, accessed October 29, 2016. Share of services data from the Bureau of Economic Analysis Table "U.S. International Trade in Services by Major Category, Exports" for the year 2001. Zeros used for industries where exports are not reported.
} 
Table 7 IV estimates: the causal impact of demand on industrial wages, US 1997-2013

\begin{tabular}{|c|c|c|c|c|}
\hline & \multicolumn{2}{|c|}{$\begin{array}{l}\text { Vacancy rate } \\
\text { Demand measure }\end{array}$} & \multicolumn{2}{|c|}{$\begin{array}{l}\text { Net hiring flow } \\
\text { Demand measure }\end{array}$} \\
\hline & (1) & (2) & (3) & (4) \\
\hline & $D_{i t}$ & $\ln w_{i \ell t}$ & $D_{i t}$ & $\ln w_{i \ell t}$ \\
\hline Demand (D) & & $\begin{array}{l}0.215 * * * \\
(0.027)\end{array}$ & & $\begin{array}{l}3.819 * * * \\
(0.526)\end{array}$ \\
\hline IV (Z) & $\begin{array}{l}12.533 * * * \\
(0.938)\end{array}$ & & $\begin{array}{l}0.764 * * * \\
(0.087)\end{array}$ & \\
\hline Share male & $\begin{array}{l}-0.665^{* * * *} \\
(0.058)\end{array}$ & $\begin{array}{l}0.311 * * * \\
(0.027)\end{array}$ & $\begin{array}{l}-0.059 * * * \\
(0.005)\end{array}$ & $\begin{array}{l}0.396 * * * \\
(0.034)\end{array}$ \\
\hline Share University Ed. & $\begin{array}{l}-2.290^{* * *} \\
(0.056)\end{array}$ & $\begin{array}{l}0.782 * * * \\
(0.066)\end{array}$ & $\begin{array}{l}-0.186^{* * * *} \\
(0.005)\end{array}$ & $\begin{array}{l}1.018^{* * * *} \\
(0.101)\end{array}$ \\
\hline Share age $<25$ & $\begin{array}{l}0.577 * * * \\
(0.085)\end{array}$ & $\begin{array}{l}-0.740^{* * * *} \\
(0.034)\end{array}$ & $\begin{array}{l}0.173^{* * * *} \\
(0.007)\end{array}$ & $\begin{array}{l}-1.286^{* * *} \\
(0.097)\end{array}$ \\
\hline Share age $25-45$ & $\begin{array}{l}0.795 * * * \\
(0.075)\end{array}$ & $\begin{array}{l}-0.048 \\
(0.034)\end{array}$ & $\begin{array}{l}0.196 * * * \\
(0.007)\end{array}$ & $\begin{array}{l}-0.657^{* * *} \\
(0.106)\end{array}$ \\
\hline Share full-time & $\begin{array}{l}1.382 * * * \\
(0.076)\end{array}$ & $\begin{array}{l}0.763 * * * \\
(0.050)\end{array}$ & $\begin{array}{l}0.029 * * * \\
(0.007)\end{array}$ & $\begin{array}{l}0.912 * * * \\
(0.035)\end{array}$ \\
\hline Union share & $\begin{array}{l}-0.474 * * * \\
(0.032)\end{array}$ & $\begin{array}{l}0.002 \\
(0.018)\end{array}$ & $\begin{array}{l}-0.072 * * * \\
(0.003)\end{array}$ & $\begin{array}{l}0.182 * * * \\
(0.041)\end{array}$ \\
\hline Share firm size $<10$ & $\begin{array}{l}1.300 * * * \\
(0.082)\end{array}$ & $\begin{array}{l}-0.545^{* * * *} \\
(0.046)\end{array}$ & $\begin{array}{l}0.063^{* * * *} \\
(0.007)\end{array}$ & $\begin{array}{l}-0.513^{* * *} \\
(0.047)\end{array}$ \\
\hline Share firm size $10-99$ & $\begin{array}{l}0.875 * * * \\
(0.070)\end{array}$ & $\begin{array}{l}-0.271 \text { *** } \\
(0.035)\end{array}$ & $\begin{array}{l}0.040^{* * * *} \\
(0.006)\end{array}$ & $\begin{array}{l}-0.249^{* * *} \\
(0.035)\end{array}$ \\
\hline Employment & $\begin{array}{l}0.608 * * * \\
(0.080)\end{array}$ & $\begin{array}{l}-0.339 * * * \\
(0.033)\end{array}$ & $\begin{array}{l}-0.098^{* * *} \\
(0.007)\end{array}$ & $\begin{array}{l}0.162 * * * \\
(0.062)\end{array}$ \\
\hline Constant & $\begin{array}{l}0.275^{* *} \\
(0.108)\end{array}$ & $\begin{array}{l}9.419 * * * \\
(0.044)\end{array}$ & $\begin{array}{l}0.869 * * * \\
(0.010)\end{array}$ & $\begin{array}{l}6.904 * * * \\
(0.385)\end{array}$ \\
\hline State dummies & YES & YES & YES & YES \\
\hline Industry dummies & YES & YES & YES & YES \\
\hline Year dummies & YES & YES & YES & YES \\
\hline Observations & 8,883 & 8,883 & 10,993 & 10,993 \\
\hline \multicolumn{5}{|l|}{ First-stage tests } \\
\hline $\mathrm{F}(\mathrm{CD})$ & 178.57 & & 76.740 & \\
\hline SY C.V. $5 \%$ & 16.38 & & 16.38 & \\
\hline
\end{tabular}

Source: IPUMS March CPS 1997-2013 and JOLTS 2001-2013. 2SLS estimates comparable to column 4 of Tables 2 and 3. Columns (2) and (4) are second-stage estimates, columns (1) and (3) are first-stage estimates. F(CD) is the Cragg-Donald F statistic (Cragg and Donald 1993). F(CD) larger than SY Stock and Yogo (2005) critical values for 5\% Wald test distortions provides more concrete grounds for rejecting the null of weak instruments. Sargan tests not available as model is just identified. Instrumental variable = Aggregate Exports/GDP $\times 2001$ Industrial share of total exports: $z_{i t}=\frac{E X P_{t}}{G D P_{t}} \times \frac{E X P_{i, 2001}}{\sum_{i} E X P_{i, 201}}=Q_{t} \cdot Y_{i}$. Vacancy rate data series starts in 2001. Net hiring flow series has imputed values for 2005. Standard errors in parentheses clustered by Industry. ${ }^{* * *} \mathrm{p}<0.01, * * \mathrm{p}<0.05, * \mathrm{p}<0.1$. Employment measured per 100 million 
for cross-industry substitution in export shares in response to industrial differences in wages and the resulting shifts in domestic demand. The instrument should also not be weak because exports are an important component of US GDP, contributing $13 \%$ to GDP in 2013.

Table 7 provides 2SLS estimates of the model in Eq. 5 with industry and state fixed-effects $I$ and $L$, the preferred specification, in which the coefficient $\beta_{1}$ can be interpreted as the causal impact of export-based demand changes on industrial wages. The first stage equation is given by Eq. 8 below.

$$
\begin{aligned}
d_{i l t}= & \gamma_{0}+\gamma_{1} z_{i t}+\gamma_{2} m_{i l t}+\gamma_{3} e_{i l t}+\gamma_{4} p_{i l t}+\gamma_{5} u_{i l t}+\gamma_{6} c_{i l t}+\gamma_{7} n_{i l t} \\
& +\mathbf{a}_{i l t}^{\prime} \xi+\mathbf{s}_{i l t}^{\prime} \phi+\tau_{t}+\mathbf{I}_{i}+\mathbf{L}_{l}+\epsilon_{i l t}
\end{aligned}
$$

The first-stage results are shown in columns (1) and (3) of Table 7 for the vacancy and net hiring flow of hiring measurements respectively. First stage estimates for the vacancy demand measure, using data for the years 2001-2013, suggest that the instrument has substantial predictive power. The coefficient $\gamma_{1}$ is positive and highly significant which indicates that predicted exports are positively correlated to industry-specific vacancy rates. The Cragg and Donald (1993) F-statistic for the significance of the excluded instrument is well above the Stock and Yogo (2005) critical values, which indicate the size of the potential distortion in a 5\% Wald test due to a weak instrument. Thus, the instrument is not weak. First-stage estimates for the net hiring flow measure also suggest the instrument has sufficient predictive power. The null hypothesis of a 5\% size distortion can be rejected, and the F-statistic is well in excess of the "rule of thumb" value of 10 .

Second-stage estimates of the impact of demand changes are provided in columns (1) and (3) for the vacancy and net hiring flow measures of demand, respectively. In both cases, the causal impact is positive and significant. These estimates are based on exogenous variation in exports and thus may not be fully representative of all demand changes in the US economy over this period. Nevertheless, they confirm the existence of an important causal effect of industrial aggregate demand on industrywage differentials.

\section{Discussion and Conclusions}

This paper examined the effects of human capital, industry structure and macroeconomic demand on industry earnings for the US. The first important result is that the level of aggregate demand in an industry in a state relative to the average across all US states and industries has a strong positive effect on average earnings of that industry in the specific state. Importantly, the national-level vacancy rate by industry holds more predictive power relative to proxies based on the net hiring flow of workers. Interestingly, in addition to the important effects on macroeconomic demand on industry earnings differentials, the study also confirms the well-established empirical and theoretical evidence that both supply side human capital characteristics and 
demand side industry characteristics are important factors to industry average earnings in line with the previous literature. The results make a clear contribution to the literature, embracing and extending previous knowledge about the determinants of industry average earnings. The results highlight that worker ability is not the sole determinant of industry earnings differentials. Macroeconomic factors and institutional characteristics play important and significant role. These results have clear policy impact. Although they confirm the importance of education in public policy aimed at reducing low-paid employment, they also advocate the promotion of policies associated with macroeconomic demand-side policies. The macroeconomic environment is important in addressing problems of low pay. The results suggest that demand-reducing policies that typically characterise austerity packages will have adverse effects in terms of achieving a productive, high-wage economy.

\section{Compliance with Ethical Standards}

Conflict of interests The authors declare that they have no conflict of interest.

Open Access This article is licensed under a Creative Commons Attribution 4.0 International License, which permits use, sharing, adaptation, distribution and reproduction in any medium or format, as long as you give appropriate credit to the original author(s) and the source, provide a link to the Creative Commons licence, and indicate if changes were made. The images or other third party material in this article are included in the article's Creative Commons licence, unless indicated otherwise in a credit line to the material. If material is not included in the article's Creative Commons licence and your intended use is not permitted by statutory regulation or exceeds the permitted use, you will need to obtain permission directly from the copyright holder. To view a copy of this licence, visit http://creativecommonshorg/licenses/by/4.0/.

\section{Appendix}

Table 8 Industry codings

\begin{tabular}{lll}
\hline IND & & IPUMS \\
Code & Industry title & IND1990 \\
\hline 1 & Agriculture, mining and forestry & $0-50$ \\
2 & Construction & 60 \\
3 & Manufacturing & $100-392$ \\
4 & Transport, trade and utilities & $400-691$ \\
5 & Finance banking and business services & $700-760$ \\
6 & Personal services, including heath & $812-871$ \\
7 & Entertainment and recreation & $761-810$ \\
8 & Professional services & $872-893$ \\
9 & Public administration & $900-932$ \\
\hline
\end{tabular}

Our one-digit industry codings are based on the IPUMS IND1990 codings embedded in the CPS data. These groupings follow closely to the NAICS (North American Industrial Classification System) codings. However, the IPUMS codings assign all construction workers a single code 


\section{References}

Abowd JM, Kramarz F, Lengermann P, Roux S (2012) Persistent inter-industry wage differences: rent sharing and opportunity costs. IZA J Labor Econ 1:1-25

Amiti M, Davis D (2012) Trade, firms, and wages: theory and evidence. Rev Econ Stud 79:1-36

Angrist JD, Pischke J-S (2009) Mostly Harmless Econometrics. Princeton University Press, Princeton

Autor D, Levy F, Murnane R (2003) The skill content of recent technological change: an empirical exploration. Q J Econ 118:1279-1333

Autor DH, Katz LF, Kearney MS (2008) Trends in US wage inequality: revising the revisionists. Rev Econ Stat 90:300-323

Baker M, Fortin N (2001) Occupational gender composition and wages in Canada, 1987-1988. Can J Econ $34: 345-376$

Becker GS (1962) Investment in human capital: a theoretical analysis. J Polit Econ 70:9-49

Becker GS (1964) Human Capital: A Theoretical and Empirical Analysis, with Special Reference to Education. Columbia Univ. Press (for the National Bureau of Economic Research), New York

Beeson P, Shore-Sheppard L, Shaw K (2001) Industrial change and wage inequality: evidence from the steel industry. Ind Labour Relat Rev 54:466-483

Ben-Porath Y (1967) The production of human capital and the life cycle of earnings. J Political Econ 75:352-365

Blanchflower DG, Oswald AJ (1995) Estimates of the economic return to schooling for 28 countries. J Econ Perspect 9:153-167

Blau FD, Kahn LM (2000) Gender differences in pay. J Econ Perspect 14:75-99

Blau FD, Kahn LM (2006) The U.S. Gender Pay Gap in the 1990s: Slowing Convergence. Indus Lab Relat Rev 60:45-66

Bluestone B (1970) Low wage industries and the working poor. Poverty and Human Resource Abstracts $3: 1-14$

Borjas G, Ramey V (2000) Market responses to interindustry wage differentials, NBER working papers 7799 , national bureau of economic research Inc

Brown S, Sessions J (2003) Earnings, education and fixed term contracts. Scott J Political Econ 50:492506

Cahuc P, Postel-Vinay F, Robin J (2006) Wage bargaining with on-the-job search: theory and evidence. Econometrica 74:323-364

Cameron AC, Gelbach JB, Miller DL (2008) Bootstrap-based improvements for inference with clustered errors. Rev Econ Stat 90:414-427

Card D (1999) The causal effect of education on earnings. Handbook of Labor Economics 3:1801-1863

Cragg J, Donald S (1993) Testing identfiability and specification in instrumental variables models. Economet Theor 9:222-240

Dickens W, Katz L (1987) Inter-industry wage differences and industry characteristics. In: Lang K, Leonard J (eds) Unemployment and the Structure of Labor Markets. Blackwell, London, pp 48-89

Du Caju P, Lamo A, Poelhekke S, Kátay G, Nicolitsas D (2010) Inter-industry wage differentials in EU countries: what do cross-country time varying data add to the picture? J Eur Econ Assoc 8:478-486

Dustmann C, Ludsteck J, Schönberg U (2009) Revisiting the german wage structure. Q J Econ 124:843881

Fazzari SM, Ferri P, Greenberg E (1998) Aggregate demand and firm behavior: a new perspective on Keynesian microfoundations. Journal of Post Keynesian Economics 20:527-558

Gannon B, Plasman R, Rycx F, Tojerow I (2005) Inter-industry wage differentials and the gender wage gap: evidence from European countries, Discussion Paper 1563 IZA

Gibbons R, Katz LF (1992) Does unmeasured ability explain inter-industry wage differentials? Rev Econ Stud 59:513-535

Goldberg P, Pavcnik N (2005a) Short-term consequences of trade reform for industry employment and wages: survey of evidence from Colombia. World Econ 28:923-939

Goldberg P, Pavcnik N (2005b) Trade, wages, and the political economy of trade protection: evidence from the Colombian trade reforms. J Int Econ 66:75-105

Goos M, Manning A (2007) Lousy and lovely jobs: The rising polarization of work in Britain. Rev Econ Stat 89:118-133

Goos M, Manning A, Salomons A (2009) Job polarization in europe. Am Econ Rev 99:58-63

Grove WA, Hussey A, Jetter M (2011) The gender pay gap beyond human capital. J Hum Resour 46:827874 
Heckman JJ, Lochner LJ, Todd PE (2003) Fifty years of Mincer earnings regressions, Technical Report National Bureau of Economic Research

Hirsch BT (2005) Why do Part-Time workers earn less? the role of worker and job skills. Ind Labor Relat Rev 58:525-551

Holt CC (1969) Improving the labor market trade-off between inflation and unemployment. Am Econ Rev 59:135-146

Holt CC (1970) Job search, Phillips' wage relation and union influence: theory and evidence. Norton, New York

Juhn C, Murphy KM, Pierce B (1993) Wage inequality and the rise in returns to skill. J Polit Econ 101:410442

Kambourov G, Manovskii I (2009) Occupational mobility and wage inequality. Rev Econ Stud 76:731759

Katz LF, Murphy KM (1992) Changes in relative wages, 1963-1987: Supply and demand factors. Quarterly J Econ 107:35-78

Keynes JM (1936) The General Theory of Employment Interest and money (1936). MacMillan, London

King M, Ruggles S, Alexander J, Flood S, Genadek K, Schroeder M, Trampe B, Vick R (2010) Integrated Public Use Microdata Series, Current Population Survey Version 3.0, Machine-readable database

Krueger A, Summers LH (1988) Efficiency wages and the inter-industry wage structure. Econometrica 56:259-293

Metcalf D (1999) The low pay commission and the national minimum wage. Econ J 109:F46-66

Mincer J (1974) Schooling Experience and Earnings. Columbia University Press, New York

Modigliani F, Tarantelli E (1973) A generalization of the Phillips curve for a developing country. Rev Econ Stud 40:203-223

Moore H (1911) Laws of Wages: An Essay in Statistical Economics. New York, Augustus M Kelley

Murphy KM, Welch F (1993) Occupational change and the demand for skill, 1940-1990. The American Economic Review, pp 122-126

Oi W, Idson T (1999) Firm size and wages. In: Ashenfelter O, Card D (eds) Handbook of Labour Economics volume 3. Elsevier Science, Amsterdam, pp 2165-2214

Pugel T (1980) Profitability, concentration and Inter-Industry variation in wages. Rev Econ Stat 62:248253

Ryan P (1990) Job training, individual opportunity and low pay. In: Bowen A, Mayhew K (eds) Improving Incentives for the low Paid. Macmillan, London, pp 181-224

Sattinger MA (1993) Assignment models of the distribution of earnings. J Econ Lit 31:831-880

Schumacher E (2001) The earnings and employment of nurses in an era of cost containment. Indus Lab Relat Rev 55:116-132

Spitz-Oener A (2006) Technical change, job tasks, and rising educational demands: looking outside the wage structure. J Labor Econ 24:235-270

Stock J, Yogo M (2005) Testing for Weak Instruments in Linear IV Regression. Cambridge University Press, Cambridge, pp 80-108

Thaler RH (1989) Interindustry wage differentials. J Econ Perspect 3:181-193

Thurow L (1957) Generating Inequality. Basic Books, New York

Tinbergen J (1956) On the theory of income distribution. Weltwirtschaftliches Arch 77:155-175

Wachtel H, Betsey C (1972) Employment at low wages. Rev Econ Stat 54:121-129

Publisher's Note Springer Nature remains neutral with regard to jurisdictional claims in published maps and institutional affiliations. 